\title{
A SURVEY OF THE GEMSTONE RESOURCES OF CHINA
}

By Peter C. Keller and Wang Fuquan

The People's Republic of China has recently placed a high priority on identifying and developing its gemstone resources. Initial exploration by teams of geologists throughout China has identified many deposits with significant potential, including amber, cinnabar, garnets, blue sapphires, and diamonds. Small amounts of ruby have also been found. Major deposits of nephrite jade as well as large numbers of gem-bearing pegmatite dikes have been identified. Significant deposits of peridot are currently being exploited from Hebei Province. Lastly, turquoise rivaling the finest Persian material has been found in large quantities in Hubei and Shaanxi Provinces.

\section{ABOUT THE AUTHORS}

Dr. Keller, a geologist and gemologist, is associate director of the Los Angeles County Museum of Natural History, Los Angeles, California; Dr. Wang is a mineralogist and gemologist at the Geological Museum, Beijing, China.

Acknowledgments: The authors thank the Geological Museum in Beijing and the Academy of Geological Sciences for inviting Dr. Keller to China. Dr. John Sinkankas was especially helpful in obtaining historical references on Chinese gem deposits.

C1986 Gemological Institute of America

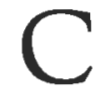
hina has historically been a land of great mystery, with natural resources and cultural treasures that, until recently, were almost entirely hidden from the outside world. From the point of view of the geologist and gemologist, one could only look at known geological maps of this huge country and speculate on the potential impact China would have on the world's gem markets if its gem resources were ever developed to their full potential.

During the past few years, the government of the People's Republic of China (P.R.C.) has opened its doors to the outside world in a quest for information and a desire for scientific and cultural cooperation. It was in this spirit of cooperation that a week-long series of lectures on gemstones and their origins was presented by the senior author and a colleague to over 100 geologists from all over China at the Geological Museum in Beijing (Peking). An important outcome of informal discussions with these geologists was a distribution map of the known gem occurrences in China (figure 1). This was the first time in its history that the Chinese Academy of Geological Sciences had held such a lecture series entirely devoted to gemstones, since only during the last decade has the P.R.C. placed any emphasis on gem materials. Jewelry and the possession of gems has not been part of the culture of the People's Republic.

The purpose of this article is to offer a brief overview of China's important gem resources as we know them at this very formative stage. There have been a number of articles both historically and recently on China's gem resources (e.g., Pumpelly, 1866; Ahnert, 1929; Sun, 1933; Ren, 1980), but these have concentrated for the most part on ornamental gem materials used in Chinese carvings. This article intentionally disregards most of these materials, except for nephrite and turquoise, in favor of materials that can be faceted and therefore may have the greatest impact on the world's gem markets in the future. While this article can in 


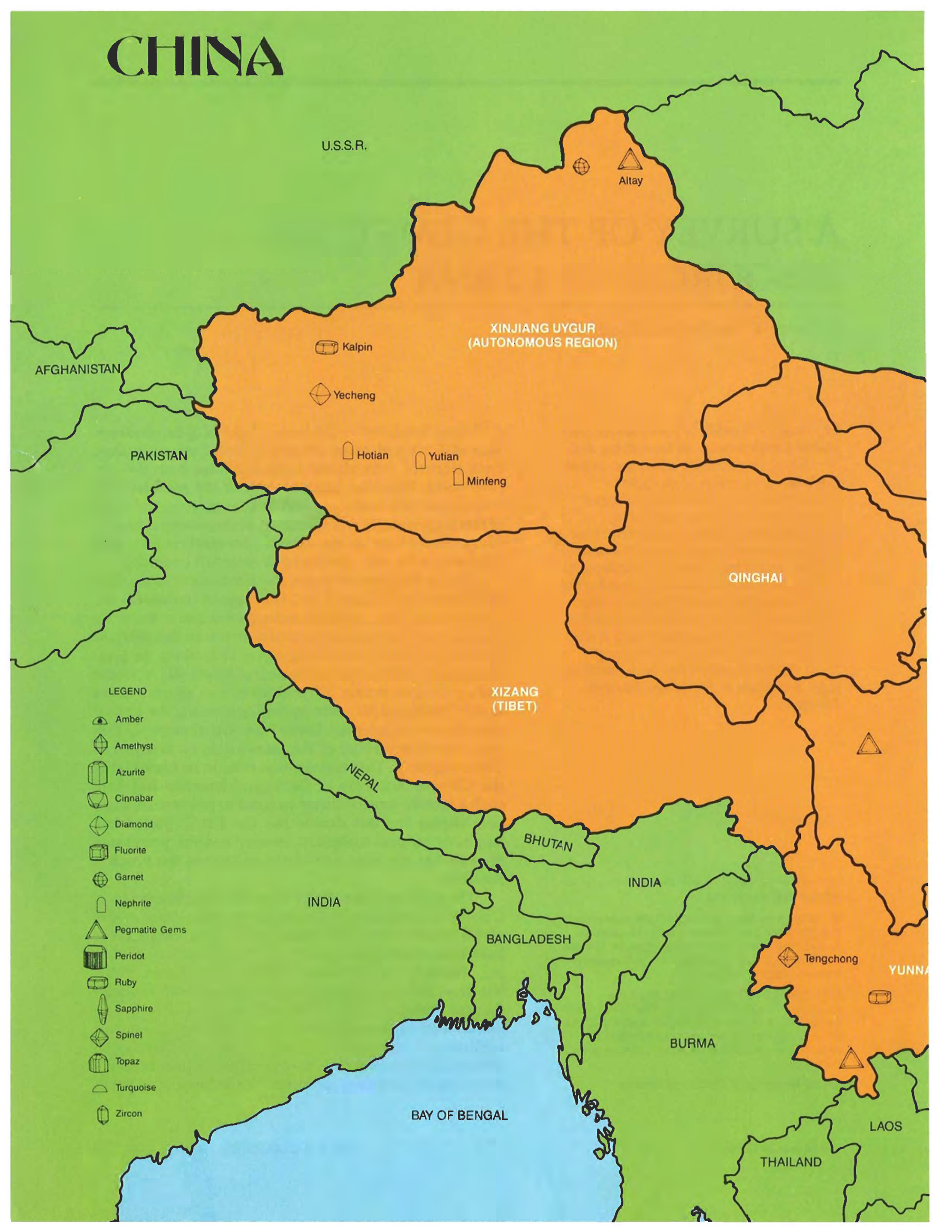




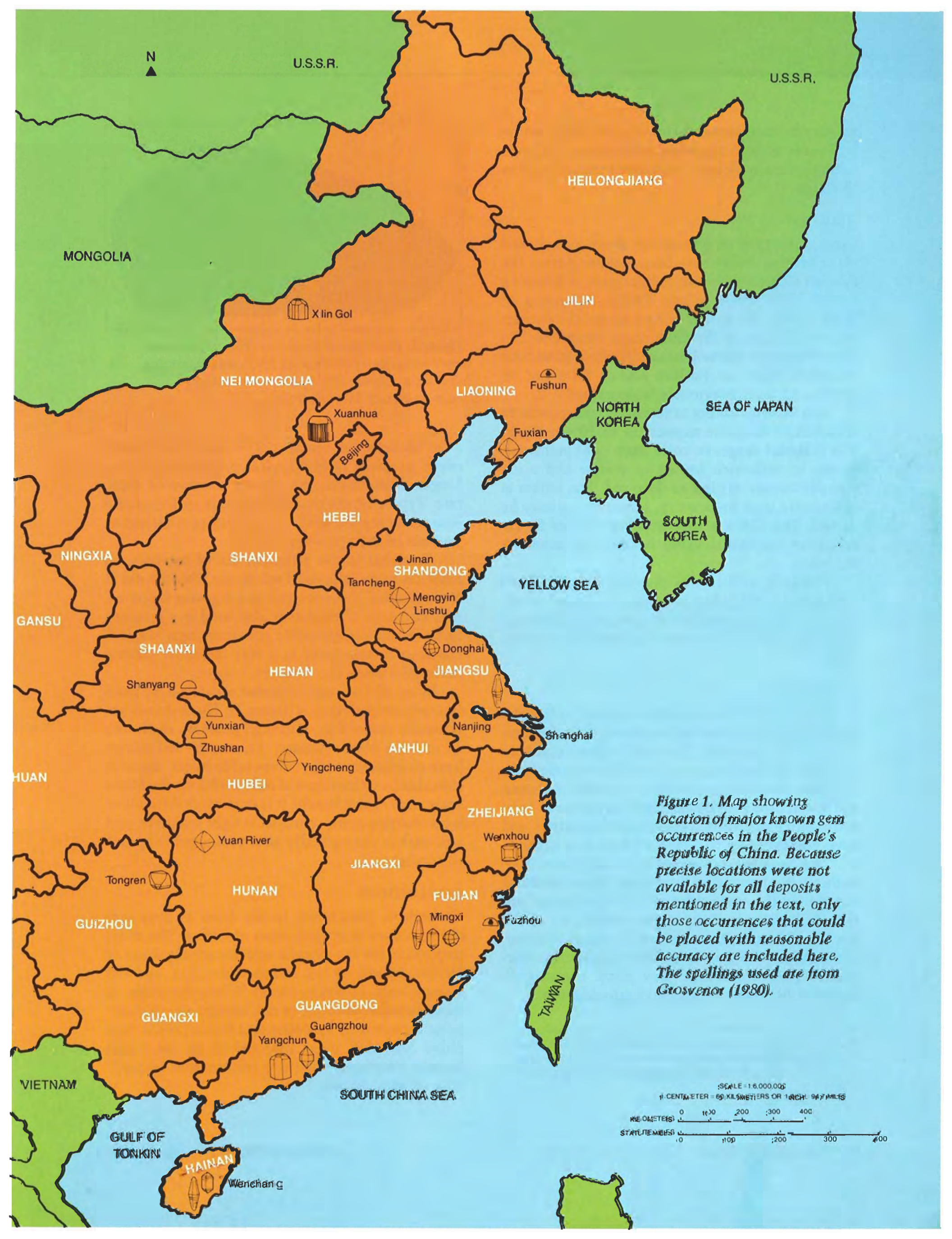


no way be considered definitive, we hope that it will serve as both an introduction and a stimulus to further research and exchange of information in this area.

\section{AMBER}

Large quantities of spectacular fossil insect- and plant-bearing amber have been recovered from the Fushun Coalfield, in the eastern part of Liaoning Province*, in northeastern China. According to Hong (1981), the amber occurs in the Eocene-age main coal seam of the Guchengzi Formation. To date, 44 species of fossil insects (figure 2) have been described from the Fushun amber. Of these 44 species, 41 were previously undescribed.

The Fushun amber is found as transparent to translucent irregular masses up to $10 \mathrm{~cm}$ thick. The material ranges in color from light yellowish brown to yellowish brown to yellow and occasionally occurs as pink or deep red. The amber is commonly used for jewelry; larger pieces may be carved. The Chinese also grind up amber for its perceived medicinal value in relieving stomach ailments.

Recently, amber was discovered in coalbeds near the city of Fuzhou in Fujian Province, southeastern China. No information on the quality and quantity of the Fujian amber is available at this time.

\section{CINNABAR}

Since the late 19th century, mineral collectors have considered China synonymous with the mercury sulfide, cinnabar. The world's finest cinnabar crystals, some as large as $6.5 \mathrm{~cm}$, have come from the Wanshanchang mines on the border of Hunan and Kweichow Provinces. These mines have been active since the Ming Dynasty (14th century), and have employed up to 5,000 workers at a time.

The cinnabar ore occurs in two horizons, 5-6 $m$ thick, in a brecciated limestone. These horizons outcrop on the steep sides of Wanshanchang Canyon. According to Tengengren (1920), one of the few Westerners to have visited the mines, the canyon is filled with wasterock from the mining operation. This wasterock has been thoroughly searched in recent times for overlooked ore.

*For the sake of consistency, place names given throughout this article and in the map in figure 1 are spelled in accordance with the National Geographic map prepared by Grosvenor (1981).

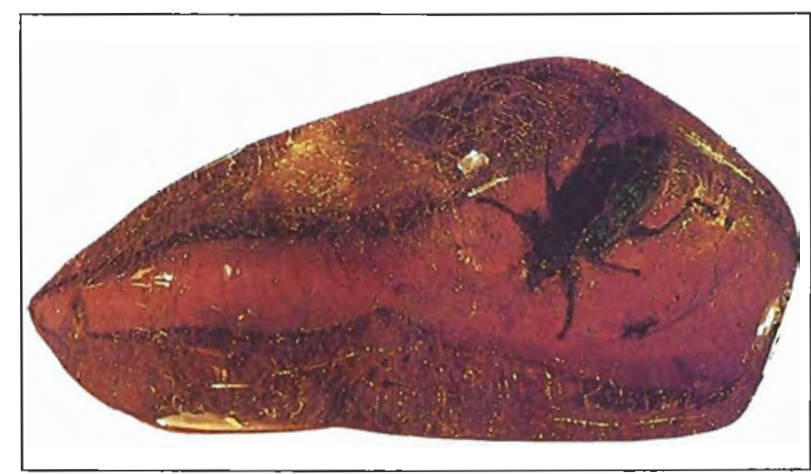

Figure 2. Fossil insect in amber from the Eoceneage coal seams of the Fushun coalfield in Liaoning Province, China. This specimen measures approximately $10 \mathrm{~cm}$ across.

The deep red cinnabar crystals almost always occur as sharp rhombohedral penetration twins. Single, untwinned crystals are considered quite rare. Typically, the cinnabar crystals are found on a limestone matrix with transparent to translucent crystals of dolomite and quartz.

Cinnabar is the principal ore of mercury. In addition to its industrial value, the Chinese use it for medicinal purposes and as a pigment for paint, ink, and dyes. Cinnabar is also used as a coloring agent in lacquer applied to wood carvings. Massive cinnabar in limestone is a very desirable carving material among the Chinese.

Some of the larger cinnabar crystals have been faceted for the collector (figure 3). These stones are generally under $3 \mathrm{ct}$, although gems up to almost $25 \mathrm{ct}$ have been recorded. These rich red stones have an adamantine to submetallic luster. Because cinnabar has a hardness of only $2-2.5$ on the Mohs scale and is quite brittle, it is extremely difficult to facet. Furthermore, cinnabar is light sensitive, and will darken dramatically after prolonged exposure to sunlight.

\section{CORUNDUM}

Corundum, principally in the form of gem sapphire, occurs in several areas of China. The most important are the Penglai and Wenchang areas of Hainan Island, in the South China Sea, and the Mingxi area in west-central Fujian Province. A more detailed account of the Mingxi sapphire deposit is presented by Keller and Keller (1986). Sapphire has also been reported from southeast Jiangsu Province, but little information is available on this deposit. 
The sapphire deposits on Hainan Island and at Mingxi are still relatively undeveloped, although they show great potential. In both instances, the deposits are thought to be the alluvial residue of alkali basalt deposits not unlike those found in Thailand and Cambodia (Jobbins and Berrange, 1981) and in Australia (Coldham, 1985). Colorless to pale yellow zircon and dark red pyrope are common accessory minerals. The sapphires themselves look very much like those found in the alluvial deposits at Anakie, Queensland, and the New England area of New South Wales, Australia. They tend to be less than $1 \mathrm{~cm}$ in length and inky bluish green to greenish blue in color, although the transparency is generally good (see photo in Keller and Keller, 1986). Active geological exploration of both areas is underway, as is experimentation with heat treatment to improve the color of the sapphire. China has the potential to become a major supplier of sapphire to the world's gem markets.

It should be noted that perfect hexagonal prisms of translucent ruby up to $1 \mathrm{~cm}$ long are being recovered from little-known deposits in Sichuan Prơvince (figure 4). Undescribed ruby has also been reported in gneiss in far western Xinjiang Uygur Autonomous Region, and in the Ailao Mountains of Yunnan Province.

\section{DIAMOND}

Perhaps no gem species evokes more excitement than diamond when one discusses the future gem potential of China. And for good reason: China has

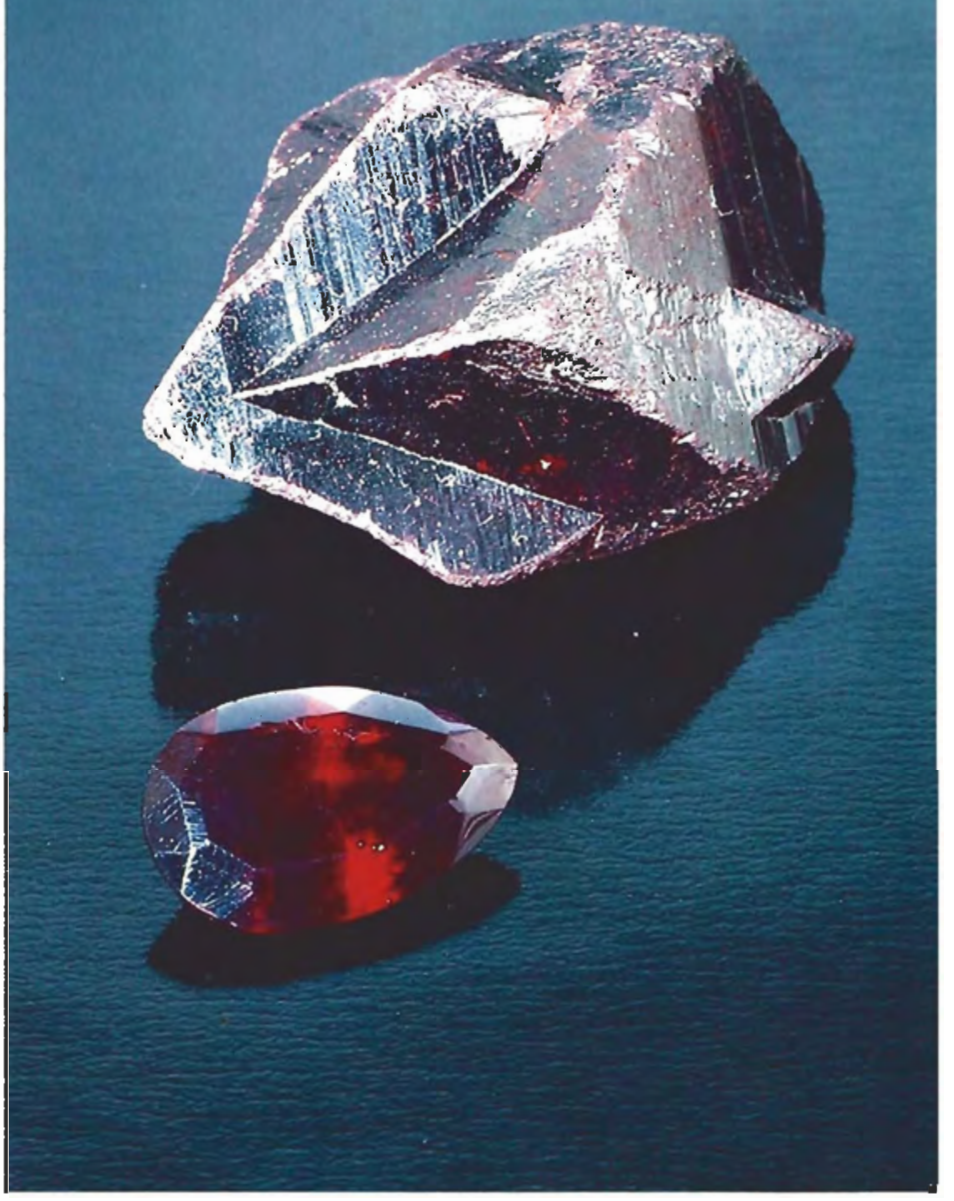

Figure 3. This cinnabar crystal and its 5-ct faceted mate come from the Wanshanchang mines on the border of Hubei and Kweichow Provinces, China. Stone faceted by Arthur Grant; photo (C) Tino Hammid.

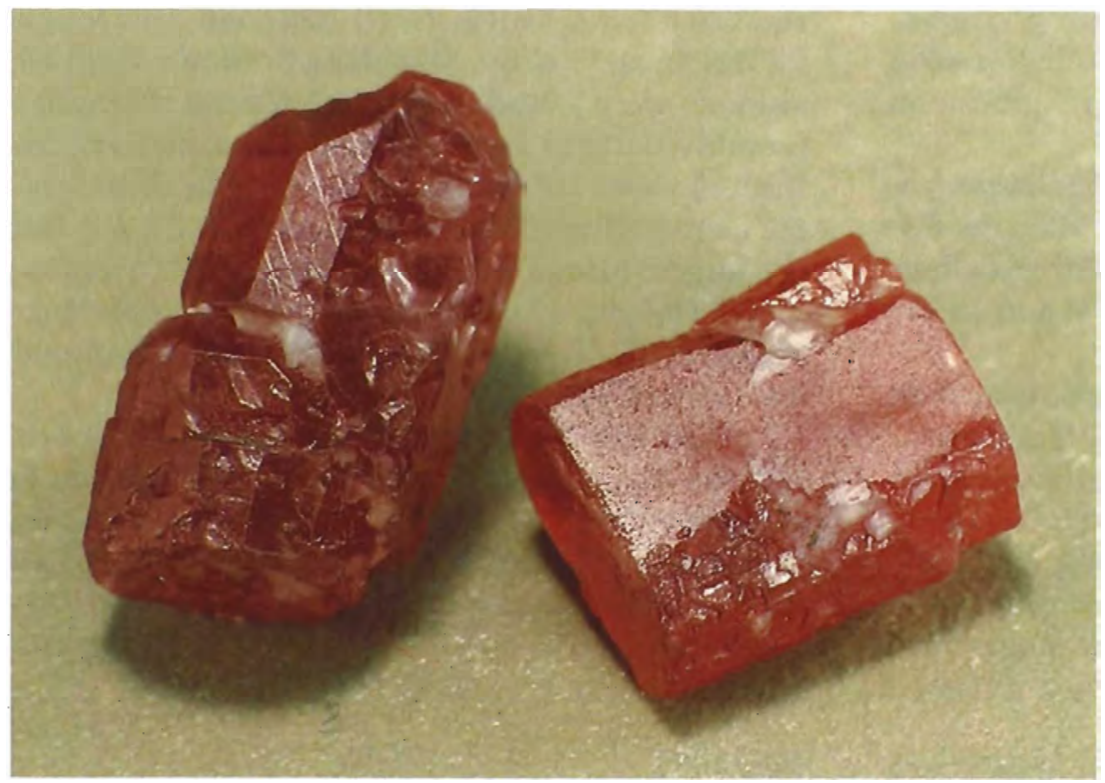

Figure 4. Hexagonal prisms of ruby averaging $5 \mathrm{~mm}$ in length from Sichuan Province, China. Photo by S. Gipson. 
Figure 5. To date, the largest gem-quality diamond found in China is the 158.79-ct Changlin diamond. This brownish yellow diamond was found in 1977 on the Jishan People's Commune in Linshu County, Shandong Province, China. Photo courtesy of the Geological Museum of China, Beijing.

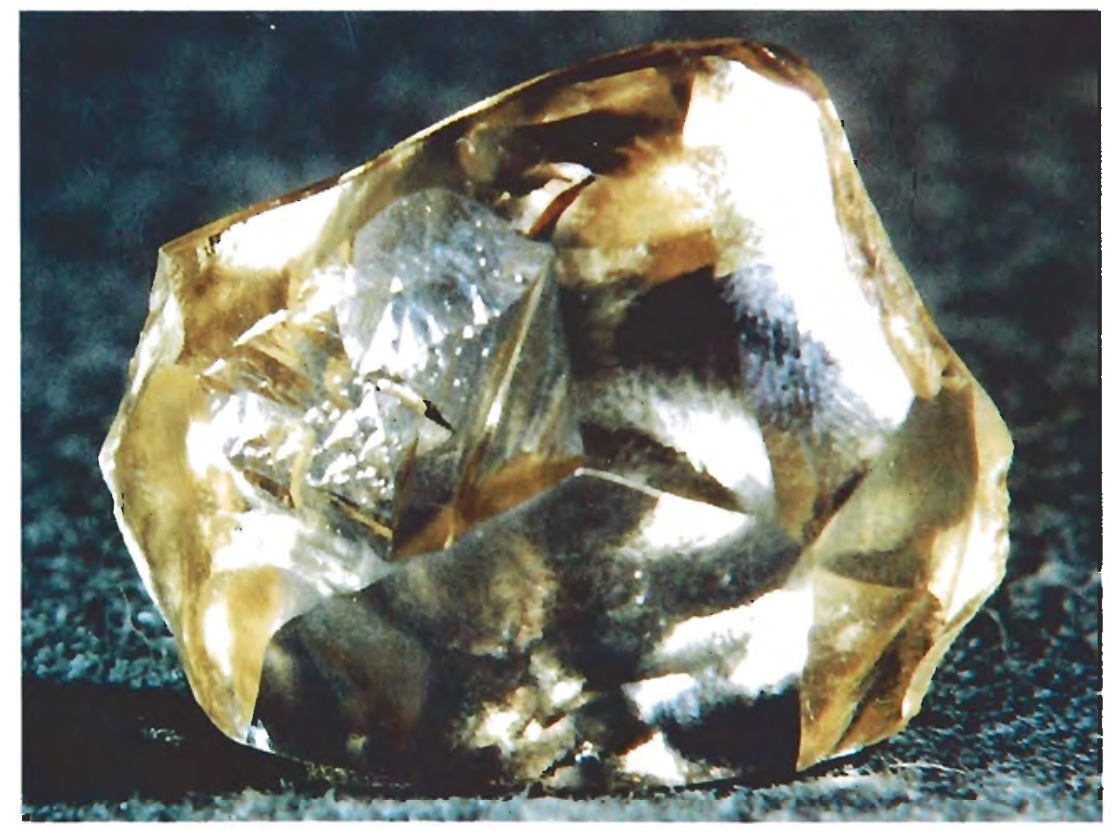

the potential, from both kimberlites and their associated alluvial deposits, to play a significant role in world diamond production. The importance of this diamond potential, as is the case with most of China's other gem resources, is only now being realized. Alluvial diamonds have been found in China since at least the late 1940s. However, it was not until 1965 that diamonds were found in their kimberlite host.

Today there are two principal diamondbearing kimberlite districts in China: the Fuxian district, in southern Liaoning Province, and the Changma district near Mengyin, in central Shandong Province. Very little has been published in the West on these two diamond-bearing kimberlites, although the Seventh Geological Exploration Team (1984) has published a paper in Chinese on the area.

A detailed description of the Mengyin-area diamond deposits, based on a recent visit, is discussed in Keller and Wan (1986). An excellent overview of Chinese kimberlites is found in $\mathrm{He}$ (1984).

As noted above, alluvial diamonds have been known in China for at least 40 years. We know of several major alluvial diamond-producing areas today. These include the Linshu and Tancheng counties south of Mengyin in Shandong Province, and the Yuan River, near Yuanling, in Hunan Province. In addition, alluvial diamonds have been found in southeastern Xinjiang Uygur Autonomous Region.

It is too early to say much about China's gem diamond potential in terms of annual production.
A reasonable, educated guess of that figure would be about $45,000-75,000$ ct per year. What is impressive, however, is the size of some of the diamonds recovered to date. The largest known gemquality diamond found in China thus far is a gemmy 158.79-ct brownish yellow modified rhombic dodecahedron known as the Changlin diamond (figure 5). This impressive diamond was found by a farmer in December 1977 on the Jishan People's Commune at Changlin in Linshu County, Shandong Province. It is interesting to note that no further exploration of the immediate area where this crystal was found has been attempted. In August 1981, the second largest diamond from China, the 124.27-ct Chengfu No. 1 diamond, was found in Tancheng County, Shandong Province. Both diamonds were found in alluvial gravels that quite possibly derived from the Changma kimberlites located about $100 \mathrm{~km}$ to the north. The third largest gem-quality diamond known from China, and the largest from a kimberlite, is the 119.01-ct diamond discovered in the Victory No. 1 pipes near Mengyin (Keller and Wan, 1986). This diamond was named Mengshan No. 1.

Although the diamond industry in China is still in its infancy, the Chinese government is committed to its rapid development. Literally thousands of geologists are currently prospecting for new deposits throughout China. It is perhaps significant that in November 1985 these geologists were joined by geologists from De Beers.

\section{GARNET}

Large numbers of chrome-bearing pyrope garnets 
occur in Quaternary alluvial deposits near Donghai, in northern Jiangsu Province, eastern China (Wang, 1984). These garnets were probably derived from the diamond-bearing kimberlites that occur in the Mengyin area of Shandong Province, about $130 \mathrm{~km}$ northwest of Donghai. Numerous alluvial diamond deposits have been identified between Donghai and Mengyin.

The pyrope garnets found near Donghai are generally very dark red and less than $1 \mathrm{~cm}$ in diameter (figure 6). They are commonly transparent and, because of their chromium content, many exhibit a distinct purple to red color change. The relatively small size of the Donghai pyropes limits their use in jewelry, although the Chinese Gem and Mineral Development Company is considering cutting the material as melee. Pyrope garnets have also been found to occur with sapphire and zircon near Mingxi in Fujian Province (see Keller and Keller, 1986), but thus far no attempt has been made to determine the economic potential of this material.

Other types of garnet found in China include grossular; demantoid, rhodolite, and spessartine. The grossulars occur in green, yellowish green, yellowish brown, and brownish red hues. Fine crystals larger than $3 \mathrm{~cm}$ in diameter have been encountered from Altay, in Xinjiang Uygur Autonomous Region, where they occur in contact metamorphic rock deposits. Gem-quality demantoids of jade green to yellowish green hues have also been found in Xinjiang Uygur Autonomous Region. The crystals occur in serpentinized pyroxene-peridotites, in association with chrome spinel and asbestos, and are generally less than $3 \mathrm{~mm}$ in diameter. The Altay pegmatite mines have produced some spessartine; the authors were recently shown a $13-\mathrm{cm}$ corroded crystal of gem spessartine similar to material from the pegmatites of Minas Gerais, Brazil, and Amelia, Virginia.

\section{NEPHRITE}

The term jade in China is often used to describe many different materials suitable for carving. For the purpose of this article, we will limit our discussion to nephrite jade. There are no known deposits of jadeite jade in China today, although the Burmese deposits of jadeite have been of great commercial interest to the Chinese since the late 18 th century.

By far the most important nephrite deposits in China are found on the northern slopes of the Kunlun Mountains in southern Xinjiang Uygur $\mathrm{Au}-$
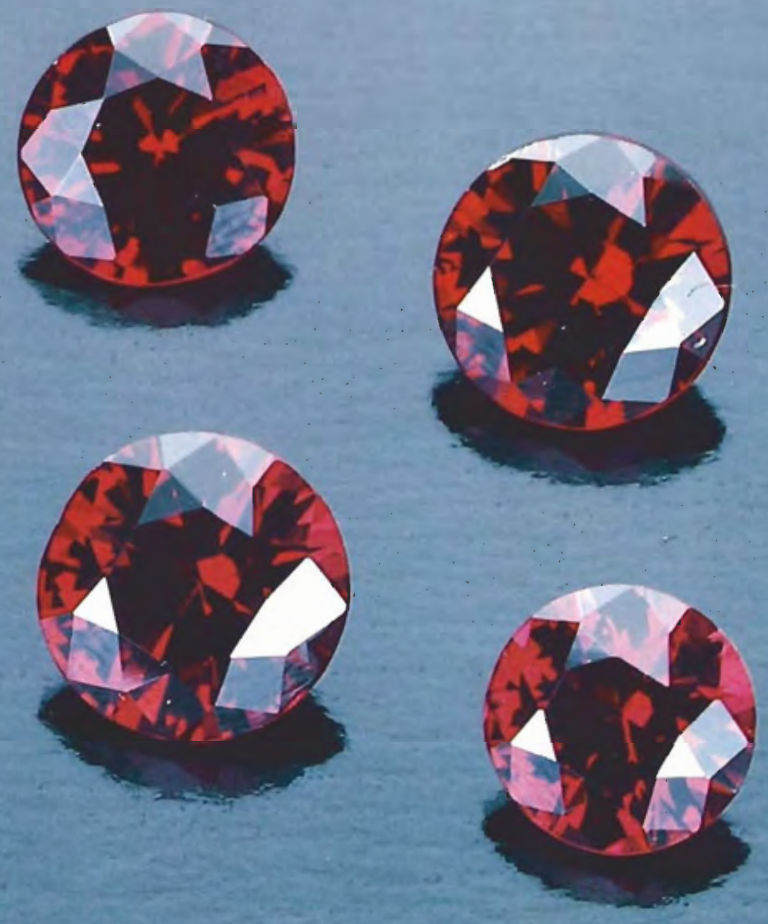

Figure 6. These faceted pyrope garnets from near Donghai in northern liangsu Province, China, average $0.20 \mathrm{ct}$ each. Stones faceted by William C. Kerr; photo (C) Tino Hammid.

tonomous Region. The principal mining centers are near the towns of Hotan, Yutian, and Minfeng. Historically, the nephrite was found as alluvial boulders near the base of the mountain. Recently, however, a contact replacement zone of nephrite was found in place in the Kunlun Mountains at an elevation of $3,000 \mathrm{~m}$ (Wang, 1979). Generally, the individual deposits of in situ nephrite were small, consisting of irregular or banded masses.

The nephrite from the Kunlun Moun tains does not differ significantly from that found in other regions of the world, such as Canada, the Soviet Union, and New Zealand. It consists of very fine grained, compact masses of tremolite and actinolite. The nephrite in the Kunlun Mountains occurs in a great variety of colors, spanning the entire spectrum. While green is the most common color, the most desirable to the Chinese is the white or "mutton fat" nephrite (figure 7). Nephrite from this area may also be called Hetian or Khotan jade, presumably referring to specific mines in the area.

Nephrite has also been reported from a number 


\section{PEGMATITE GEMS}

Granitic pegmatites are known throughout China, although only those that occur in the northwestsoutheast trending Altay Mountains of northern Xinjiang Uygur Autonomous Region are known to produce significant quantities of gem materials. Thousands of pegmatite dikes have been reported in the Altay Mountains (Chen Wen-ao, Xinjiang Altay Gemstone Technological Company, pers. comm., 1985). Of these, however, only those found just east of the city of Altay have been developed for their gem minerals.

According to Liu (1981), the Altay pegmatite region can be divided into more than 39 pegmatite provinces. The pegmatite dikes are concentrated along the contacts with the predominantly schist or gneiss country rock. As is common to granitic pegmatites elsewhere, the Altay pegmatites are concentrically zoned. Liu (1981) divides the pegmatites into nine zones, although these could be simplified into the four commonly reported zones: an aplitic (sugary) border zone; the thicker, more coarsely crystalline well zone containing abundant muscovite, feldspar, and beryl; an intermediate zone containing very large crystals of quartz, feldspar, mica, and some gem minerals; and, finally, the core zone consisting of massive quartz and feldspar. Most of the gem material recovered to date has been recovered from the primary pegmatite rather than from secondary deposits.

A total of 74 minerals have been reported from the Altay pegmatite dikes. Many of these are rare minerals such as ixiolite, but almost all of the gem minerals that one associates with pegmatitesi.e., tourmaline (figure 8), spodumene, beryl (figure 8), spessartine garnet, smoky quartz, and moonstone-have been found. Fine gem topaz appears to be absent from the Altay area, although very fine pale blue-green and rich yellow to red topaz crystals up to $24 \mathrm{~cm}$ in length have been found in the Xilingeleimeng of Inner Mongolia Autonomous Region, as well as in southern Yunnan Province.

It should also be noted that very fine tabular aquamarine, morganite, and goshenite crystals up to $5 \mathrm{~cm}$ in diameter have been recovered from pegmatites in Sichuan Province in central China.

To date, of all the Altay pegmatite gems, the various colors of beryl have shown the greatest commercial promise. Greenish yellow gemquality beryl crystals up to $15 \mathrm{~cm}$ long and $5 \mathrm{~cm}$

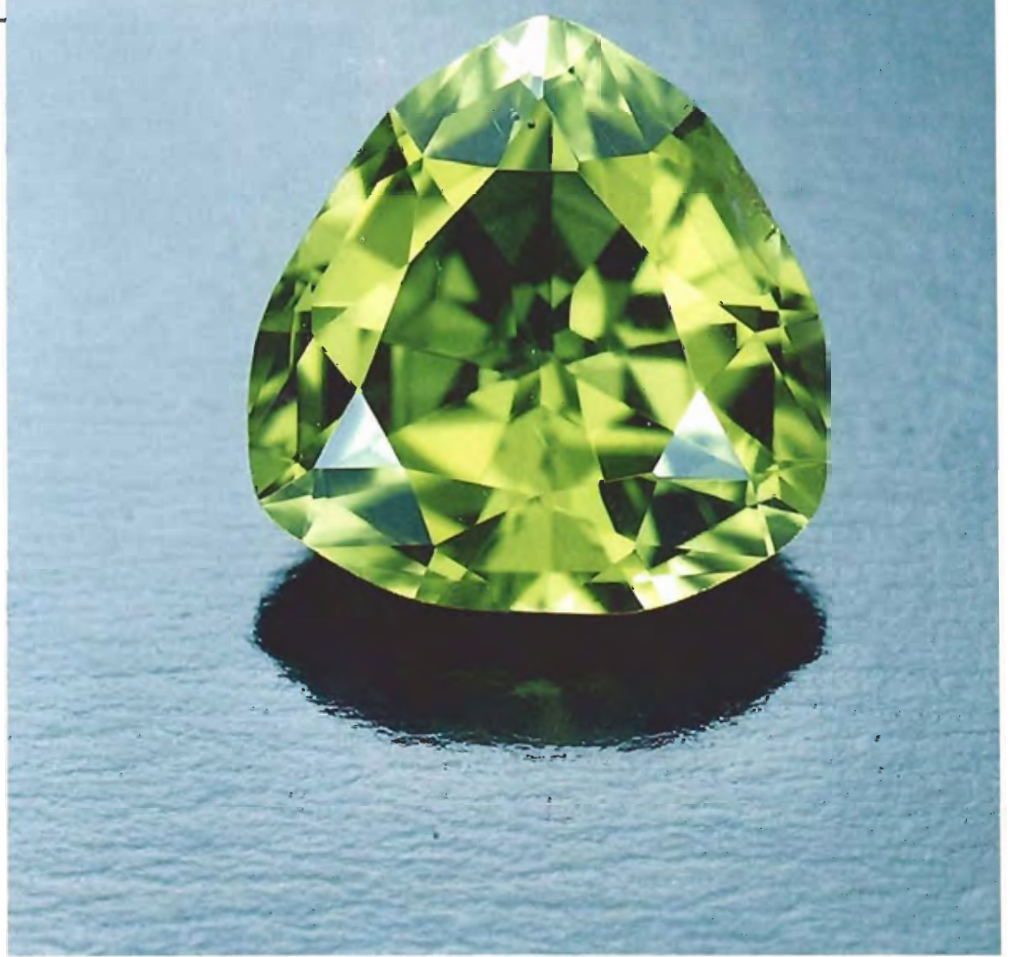

Figure 9. This 2.87-ct peridot is from the

Zhangiakou-Xuanhua area of Hebei Province, China. Stone faceted by William C. Kerr; photo (c) Tino Hammid.

wide have been seen by the authors. Large quantities of pale blue, finely developed aquamarine crystals have also been recovered and have, in fact, been observed on the mineral specimen market in the United States. It is unfortunate that until only recently, many of the beryl crystals were recovered for their industrial rather than gem value. The Altay pegmatites have yielded industry-grade beryl in crystals over $52 \mathrm{~cm}$ in length.

The Altay pegmatites have also produced gem tourmaline in red, green, yellow, and (in rare instances) blue hues. Gemmy pink tourmalines, some as large as $15 \mathrm{~cm}$ in diameter, have been reported. Very fine bicolored red-green crystals have also been observed up to $6 \mathrm{~cm}$ in length. In addition to beryl and tourmaline, crystals of kunzite and green to yellowish green gem spodumene have been found in sizes up to $20 \mathrm{~cm}$.

\section{PERIDOT}

Gemmy pieces of attractive green peridot up to at least $5 \mathrm{~g}$ in weight are currently being produced from the base of the Tertiary-age Hanluoba basalt lava flows in the Zhanjikou-Xuanhua area of Hebei Province, about $150 \mathrm{~km}$ northwest of Beijing (figure 91. This deposit was discovered in 1979 by the 


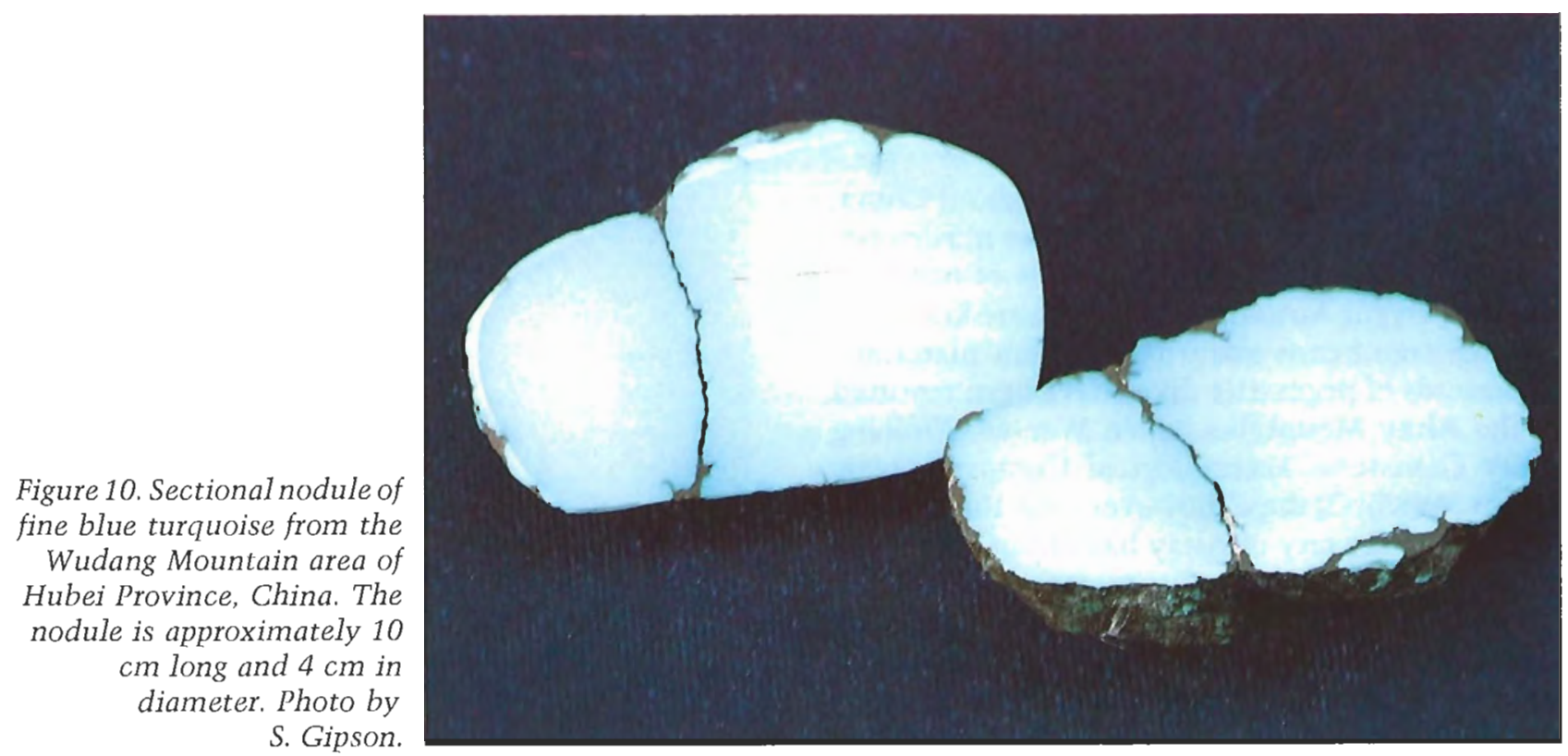

Ministry of Geology and Mineral Resources. Little more is known at this time about the occurrence of the Chinese peridot, although a recent gemological study of samples from this area indicates that the material resembles peridot from San Carlos (Arizona) and may have occurred in a similar fashion. Interestingly, the Chinese peridots appear to be somewhat harder than their San Carlos counterparts and thus produce a polish comparable to the Burmese material (Koivula and Fryer, 1986). It can be safely assumed, however, that significant amounts of the material will be seen on the world's gem market in the future. The Chinese Gem and Mineral Development Company in Beijing is actively acquiring the rough material and faceting it for commercial distribution.

\section{TURQUOISE}

It is generally accepted that the finest turquoise in the world comes from the Nishapur district of Iran, and hence "Persian turquoise" has become a trade term for the top grade of turquoise. China is now producing turquoise that rivals the finest of the traditional "Persian" (figure 10). It is uncertain as to just when the Chinese began mining turquoise although it has been popular in China for jewelry and carvings for many centuries, much of the material could have been obtained from trading partners to the west. Still, archeological finds of turquoise carvings that date as early as 1300 B.C. indicate that China's own deposits may have been exploited for many centuries without the knowledge of the outside world. Many of the carvings now sold in Hong Kong are undoubtedly made of Chinese material.

Today, significant deposits of very fine turquoise are mined at Yunxian and Zhushan in the Wudang Mountain area of northwestern Hubei Province, and near Shanyang in Shaanxi Province, about $150 \mathrm{~km}$ northwest of the Wudang Shan area. The gemological properties of Chinese turquoise are discussed in detail by Wang (1986).

The turquoise from Hubei and Shaanxi occurs as compact nodules on or very near the surface of the ground. Nodules up to $8 \mathrm{~cm}$ are relatively common, and masses several times that size have been observed. The Geological Museum in Beijing has a 24-cm-high, 3,000-g turquoise statue called the Nine Lions which is carved of material from Hubei Province (Wang, 1986). The Chinese turquoise ranges in color from various shades of blue to light green with increasing iron content. It is not unusual to find perfectly homogenous masses, although very fine "spider web" nodules have also been observed.

\section{CONCLUSION}

A number of other gem materials have been reported from China. These include fluorite from Wenxhou Province, zircon from Fujian Province, and amethyst and azurite from Guangdong Province. Given the size and varied geology of the country, it is likely that many other gem materials, as well as other deposits of materials already identified, will be found as the current program of exploration and research continues. 


\section{REFERENCES}

Ahnert E.E. (1929) Mineral resources of North Manchuria. In The Geological Survey of China, Memoirs, Series A, No. 7 .

Coldham T. (1985) Sapphires from Australia. Gems \&) Gemology, Vol. 21, No. 3, pp. 130-146.

Grosvenor G. ed. (1980) People's Republic of China. Map produced by the Cartographic Division of the National Geographic Society, Washington, DC.

He Guan-Zhi (1984) Kimberlites in China and their major components: a discussion on the physico-chemical properties of the upper mantle. In J. Kornprobst, ed., Kimberlites, 1: Kimberlites and Related Rocks, Elsevier, New York, NY.

Hong Youchong (1981) Eocene fossil diptera (insecta) in amber of Fushun coalfield. Geological Publishing House, Beijing.

Jobbins E.A., Berrangé J.P. (1981) The Pailin ruby and sapphire gemfield, Cambodia. Journal of Gemmology, Vol. 17, No. 8 , pp. $555-567$.

Keller A.S., Keller P.C. (1986) The sapphires of Mingxi, Fujian Province, China. Gems \&) Gemology, Vol. 22, No. 1, pp. $41-45$.

Keller P.C., Wan Guo-dong (1986) The Changma diamond district, Mengyin, Shandong Province, China. Gems \&) Gemology, Vol. 22, No. 1, pp. 14-23.

Koivula J.l., Fryer C.W. (1986) The gemological characteristics of Chinese peridot. Gems \&) Gemology, Vol. 22, No. 1, pp. $38-40$.
Liu Guobin (1981) Gem minerals of China. Journal of the Gemological Society of Japan, Vol. 8, No. 1-4, pp. 5-15.

Pumpelly R. (1866) Geological researches in China, Mongolia, and Japan. Smithsonian Contributions to Knowledge, No. 202, pp. 116-118.

Ren Kai-wen (1980) Minerals in China. Shanghai Scientific and Technical Publishers, Shanghai, China.

Seventh Geological Exploration Team (1984) Changma kimberlite, Mengyin, Shandong Province (in Chinese) Unpublished.

Sun C.C. (1933) Notes of the precious stone (beryl, etc.) deposits of Sichuan. Geological Society of China Bulletin, No. 12, pp. $275-282$.

Tengengren F.R. (1920) The quicksilver deposits of China. Geological Survey of China Bulletin, No. 2, pp. 1-35.

Wang Fuquan (1979) Precious stones found in China. Lapidary Journal, vol. 33, No. 3, pp. 694-696.

Wang Fuquan (1984) Study on gemological mineralogy of chromium-containing pyropes of Jiangsu Province. Acto Petrologica Mineralogica et Analytica, Vol. 3, No. 1, pp. 33-39.

Wang Fuquan (1986) A gemological study of turquoise in China. Gems \&) Gemology, Vol. 22, No. 1, pp. 35-37.

The Gemological Institute of America wishes to extend its sincerest appreciation to all of the people who contributed to the activities of the Institute through donations of gemstones and other gemological materials. We are pleased to acknowledge many of you below:

\author{
Mr. Jonathan Allen \\ Mr. Curt Berreman \\ *Mr. R. C. Blankenhorn \\ Mr. Gary Bowersox \\ Mr. Thomas Chatham \\ Mr. Ralph D. Coello \\ Mr. Terrence Coldham \\ Mrs. R. Dargatz \\ Mr. Robert Dunnigan \\ *Ms. Carol Elkins \\ Everts Jewelers \\ Mr. Pete Flusser \\ Mr. George R. Frost \\ *Mr. E. A. Gabriel \\ Mr. Jeffery Gendler \\ Dr. Samuel E. Gendler \\ Mr. Jim Gomes \\ *Mr. Keith Gouverneur
}

\author{
${ }^{*}$ Mr. Frederick J. Goynshor \\ *Ms. Mary Hanns \\ Mr. Rex Harris \\ Mr. Sjarif Harris \\ Dr. William L. Harville, Jr. \\ ${ }^{*}$ Mr. Stephen C. Hofer \\ Inamori Laboratory, Ltd. \\ Mr. Gonzalo Jara \\ Mr. Toby Joseph \\ Mr. Joe Kalman \\ *Mr. Stelios Karamallis \\ *Ms. Margaret Kershaw \\ Mr. John Koivula \\ Mr. Don Kuehn \\ *Ms. Demetra Lalaounis \\ Mr. Bill Larson \\ Mr. Richard T. Liddicoat, Jr. \\ Ms. Pat Lineberry \\ Dr. D. Vincent Manson
}

*Mrs. C. E. Montgomery

Mr. William Mosher

Dr. Kurt Nassau

Mr. J. D. Porter

Mrs. Ruth Rothstein

Mr. Robert Saling

*Santa Monica Gemological Society

Miss Nacira Saud

Mr. and Mrs. Harold Savinar

Mr. and Mrs. Hyman Savinar

Mr. and Mrs. Lewis Savinar

Dr. James E. Shigley

Mr. David B. Sigler

Mr. Ronald Tanaka

Mr. W. Taylor

Vaniman Co.

Mr. Michael Wilson

*Mr. Kenzo Yamamoto

*Denotes book donation to GIA Library. 